\title{
THE IMPACT OF AGENCY COSTS ON FIRM PERFORMANCE: AN ANALYSIS ON BIST SME FIRMS
}

\author{
DOI: 10.17261/Pressacademia.2021.1481 \\ PAP- V.14-2021(7)-p.28-32
}

\section{Sule Baykara ${ }^{1}$, Betul Baykara²}

${ }^{1}$ Kadir Has University, Banking and Finance, Istanbul, Turkey. sule.baykara@stu.khas.edu.tr, ORCID: 0000-0002-7987-2906

${ }^{2}$ Marmara University, Banking and Insurance, Istanbul, Turkey.

betbaykara@gmail.com, ORCID: 0000-0002-9307-3406

To cite this document

Baykara S., Baykara B., (2021). The impact of agency costs on firm performance: an analysis on BIST SME Firms. PressAcademia Procedia (PAP), 14, 28-32.

Permanent link to this document: http://doi.org/10.17261/Pressacademia.2021.1481

Copyright: Published by PressAcademia and limited licensed re-use rights only.

\section{ABSTRACT}

Purpose- The basis of the modern firm structure consists of the mutual contractual relationship of the principle and agent. Accordingly, the separation of ownership and management may lead conflicts and costs to bear. Conflict of interest between managers and shareholders creates a threat to the firm's financial performance. In order to evaluate this aspect of the issue, this study examines the relationship between agency costs and the firm performance of the SME firms traded in Istanbul Stock Exchange between 2017 and 2020 . Asset utilization ratio, operating expenses ratio and the ratio of free cash flows to total assets are used to measure agency costs.

Methodology- The research data are formed by small and medium sized publicly traded firms in BIST KOBI which is extracted from Bloomberg database and KAP. 42 manufacturing companies were examined to be used in the research, and 38 companies found eligible for the analysis. Panel data analysis with 3 different regression models, which enables to control of heterogeneity effect, is conducted by using Stata 11 software package.

Findings- According to fixed effect panel data regression based on three models, only one proxy for agency cost measurement which is operating expense, is found significant for small and medium sized companies traded in Istanbul Stock Exchange Market. Other proxies (asset utilization ratio and ratio of free cash flow to total assets) are found invalid for agency cost measurement.

Conclusion- This study tries to examine the discussion of agency cost measurement based on the previous literature. The empirical part of the study presents panel data analysis on a dataset of 38 public SME firms traded in Borsa Istanbul between 2017 and 2020 . Three different models are constructed to measure the agency cost in the light of related literature. Only one proxy is found as direct measure of agency cost while others are insignificant.

Keywords: Agency costs, financial performance, Istanbul Stock Exchange, SME firms, panel data analysis JEL Codes: C23, G10, L25

\section{INTRODUCTION}

In the classical firm structure, while the capital owner manages the firm, in the modern firm structure, ownership and control are separated from each other and the firm is managed by professional managers. For the continuity and development of the company, it is necessary to provide an optimal balance structure that envisages a fair share of interests by reducing the problems between interest groups. Achieving the balance involves various costs and minimizing of these costs is the subject of agency theory.

Agency theory handles the conflict of interest between principles and agents and whenever managers of the firms have incentives to act their own interest agency cost may occur. The problem of aligning the interests of owners and managers in a way to satisfy both parties became an important debate in finance and economic literature. Several studies examine how to alleviate the agency problem and reduce agency costs, also other studies discuss various mechanisms reducing agency costs and how they impact on these costs. The most prominent studies on agency theory are done by Ross (1973) and Jensen and Meckling (1976), who initially defined the principal-agent relation as set of contracts between owners (principals) and employees (agents). Jensen and Meckling (1976) stated that if the company is managed by managers which is not owner, there will be deviations from the goal of maximizing firm value. Accordingly, managers can make unnecessary expenses by acting in line with their personal interests and goals, instead of maximizing the value of the company, this causes agency problems between shareholders, creditors and company management. Agency problems may lead to agency costs such as welfare losses, monitoring and bonding costs, which reduce the value of the firm. 
Agency costs can emerge in various forms such as, managerial self-interest behaviors, perquisite consumptions, work shirking, non-optimal investment decisions, and corporate fraud (Henry, 2006). The adverse effects of these type of costs can damage the financial performance of the firm and the shareholders' wealth. The emergence of these adverse effects has stressed the effectiveness of corporate and control mechanisms related with agency cost. So, it became a key factor which reflects efficiency and effectiveness of corporate governance.

The purpose of this study is to examine the determinants of agency costs and link between agency cost and firms' financial performance listed in Istanbul Stock Exchange as SME firms. Several measurements are used to proxy the agency cost on the financial performance of firm.

This paper builds on the studies that attempt to quantify agency costs such as Ang et al. (2000), Margaritis and Psillaki (2010), Singh and Davidson (2003), and other studies that analyze the impact of agency costs on various indicators of firm performance such as Morg et al. (1988) and Andersen et al. (2003). One of the main objectives of this paper is to present the empirical evidence of the agency costs in BIST SME firms. This study also contributes the current literature in several ways to present the panel data analysis applied with 38 SME Turkish firms between 2017 and 2020 which accumulates 152 firm-year observations, and the data set is organized around the research question by using three different ratios as agency cost proxy.

\section{LITERATURE REVIEW}

The antecedents of agency concept can be pointed out to Adam Smith's essential book "The Wealth of Nations" (1776) who mentioned about the manager's problem firstly. According to Smith (1776), it cannot be expected that managers to watch other people's money in the same concern than watch of their own money. Therefore, laxity and plenty must always be, more or less, in the company's management. Berle and Means (1932), nearly 150 years later from the Smith's study, talked on the separation notion first time; firm owners as principals and firm managers as agents. They touched upon the inherent problems in the separation of ownership and control.

During the 60 's and 70 's, academicians deal with the risk sharing problem which may arise when the parties of corporations have different approach to risk sharing. Ross (1973) extends the risk sharing problem as agency relationship which arises between two or more parties. He discusses the contractual agreements between employee and employer and governed and state.

The classical and well-known study by Jensen and Meckling (1976) on the application of agency theory, expands this concerns on the behavior of agents in an explicit model. Their model grasps the agency relations within the firm. Also, Jensen (1983) aims to reveal the situation in which principal and agent are prone to have conflict goal. As mentioned, the main objective of agency theory is to understand and analyze the relationship of principal-agent.

Turning back to the current literature, agency costs are measured by some financial ratios. Some of these measurements are used to proxy the level of agency costs. One of the first study by Ang et al. (2000) provides measurement insights by using financial ratios on agency cost. They used expense ratio and asset utilization ratio as indicator of the management expenditure, how the management of firm control the operating costs, and how management of firm deploys effectively its assets. Another study is made by Wang (2010), attempts to evaluate the firm performance and agency cost relationship based on the ROA and ROE on a dataset of publicly traded firms on Taiwan Stock Exchange. Chinelo and lyiegbuniwe (2018) used asset turnover ratio, earnings before interests, taxes, depreciation to total assets, and board characteristics to determine the agency cost magnitude. Margaritis and Psillaki (2010) examined the following question "Does higher leverage lead to better firm performance around the ownership structure?" to measure the firm efficiency they use debt to total asset ratio, intangible asset ratio and tangible asset ratio and ownership structure to estimate the agency cost.

Besides the examples presented above, in Turkey, limited number of studies directly tackle the measurement of agency costs. Turaboğlu (2002) examined the firm performance and ownership structure with the dataset of 66 traded and 48 non-traded Turkish firms between 1994 and 1999. He used return on equity and Tobin's Q ratio as dependent variable and ownership structure, net sales, tangible assets and industry dummy are used as independent variables, as a result he found that ownership structure does not affect agency cost.

Akyol (2007) examined the dividend policy and agency cost on 108 traded firms in BIST between 1997 and 2002. He used ownership structure, growth rate, leverage, firm size and free cash flow as independent variables, and dividend yield as dependent variables. Results show that agency costs do not have an effect on dividend yield.

Çopuroğlu and Korkmaz (2018) investigated the relationship between agency cost and firm performance by using the ROA and ROE as dependent variable, long term liability to assets ratio, firm size, firm age, tangible asset ratio, and liquidity ratio as independent variable on BIST manufacturing firms between 2007-2017. They found that ownership structure negatively effects the firm performance.

\section{DATA AND METHODOLOGY}

Following the previous literature, this section provides the formation of research design that aims to examine the relationship between firm performance and agency cost with selected proxies. Previous literature uses operating expense ratio (OPEXR) as a direct proxy of agency costs since the management consumption are assumed to affect financial performance badly (Ang et al., 2000).

As pointed out by Jensen (1986), free cash flow (FCF) is the excess cash flow that needed for financing positive net present value projects. When it's left to the management discretion, this cash flow excess may lead to poor investment decisions.

Moreover, self-motivated behaviors of managers may lead to low level of asset utilization (ASSTUT) which shows the existence of agency cost (Jensen \& Meckling, 1976). Agency costs are likely to affect firm performance. 
The research data are formed by small and medium sized publicly traded firms in BISTKOBI which is extracted from Bloomberg database and KAP (Kamuyu Aydınlatma Platformu). 42 manufacturing companies were examined to be used in the research, and 38 companies found eligible for the analysis. Panel data analysis, which enables to control of heterogeneity effect, is conducted by using Stata 11.

\section{Dependent Variable}

-EBITDA/TA is the indicator of financial performance of the firm which shows the financial distress, firm value and operating performance.

\section{Explanatory Variables}

Three variables are used to proxy for agency costs. These are operating expense ratio (OPEXR), free cash flow ratio (FCF/TA), and asset utilization ratio (ASSTUT).

-In line with the previous literature, OPEXR is the measurement of the management effectiveness in controlling agency costs. The higher the operating expense, the higher possibility of the management activities do not contribute to income (Ang et al., 2000), (Zhang \& Li, 2008), (Rashid, 2013).

-FCF/TA is the second proxy for agency cost. Jensen (1986) states that generation of free cash flow may lead to potential conflict between managers and shareholders with respect to payout policies.

-ASSETUT ratio is the third measure of agency cost. It is computed by annual sales to total assets. It is the measurement of nonproductive asset investments of management.

\section{Control Variables}

-LASST is the natural log of total assets which is used to control for firm size.

-LEVR is the debt ratio of the firm. As outside/debt financing increases the agency cost of managers will increases (Jensen \& Meckling, 1976).

In order to test the hypothesis, panel data analysis is used. Panel data helps to control for heteroskedasticity and consists of random effect (RE), fixed effect (FE) and OLS. Hausman test is used to decide whether RE or FE is more precise. Three different models are used to test the relationship between financial performance of firms and agency costs.

$\mathrm{H}$ : The higher the level of agency costs incurred by the firm, the lower the firm's financial performance measured by EBITDA/TA.
(1) EBITDA/TA $=\beta_{0}+\beta_{1}$ OPEXR $_{\text {it }}+\beta_{2}$ LASST $_{\text {it }}+\beta_{3}$ LEVR $_{\text {it }}+\varepsilon_{\text {it }}$
(2) $\quad$ EBITDA $/ T A=\beta_{0}+\beta_{1}$ FCF $/ T A_{i t t}+\beta_{2}$ LASST $_{i t}+\beta_{3}$ LEVR $_{\text {it }}+\varepsilon_{i t}$
(3) $\quad$ EBITDA/TA $=\beta_{0}+\beta_{1}$ ASSETUT $_{i t}+\beta_{2}$ LASST $_{i t}+\beta_{3}$ LEVR $_{i t}+\varepsilon_{i t}$

\section{FINDINGS}

This section provides the statistical findings.

Table 1: Descriptive Statistics for the Complete Sample (Sample contains BIST SME firms (ХKOBI) between 2017-2020.)

\begin{tabular}{|l|l|r|r|r|r|}
\hline Variable & Obs. & \multicolumn{1}{l|}{ Mean } & \multicolumn{1}{l|}{ Std. Dev. } & \multicolumn{1}{l|}{ Min } & \multicolumn{1}{l|}{ Max } \\
\hline EBITDA/TA & 152 & 0.1160 & 0.3106 & -0.6129 & 2.2672 \\
\hline OPEXR & 152 & 0.1720 & 0.2560 & 0.0070 & 2.5700 \\
\hline FCFTA & 152 & 0.0071 & 0.2468 & -0.6143 & 1.9215 \\
\hline ASSTUT & 152 & 0.8987 & 1.2089 & 0.0002 & 12.8024 \\
\hline LASST & 152 & 18.0057 & 0.8815 & 15.4274 & 20.6672 \\
\hline LEVR & 152 & 0.2695 & 0.4985 & 0.0115 & 5.1192 \\
\hline
\end{tabular}

Table 2: Correlation Matrix of Variables

\begin{tabular}{|l|rrrrr|}
\cline { 2 - 6 } \multicolumn{1}{c|}{} & OPEXR & FCFTA & ASSTUT & LASST & LEVR \\
\hline OPEXR & 1.0000 & & & & \\
FCFTA & 0.1753 & 1.0000 & & & \\
ASSTUT & 0.7876 & 0.2932 & 1.0000 & & \\
LASST & -0.3336 & -0.1362 & -0.2890 & 1.0000 & \\
LEVR & 0.4515 & -0.0261 & 0.4189 & -0.3501 & 1.0000 \\
\hline
\end{tabular}

Table 2 shows Pearson correlation of coefficient matrix. If the correlation is higher than the reference point 0.8 then, multicollinearity problem arises. In table 2, variables are not subject of multicollinearity problem. 
Table 3: Panel Data Analysis Results

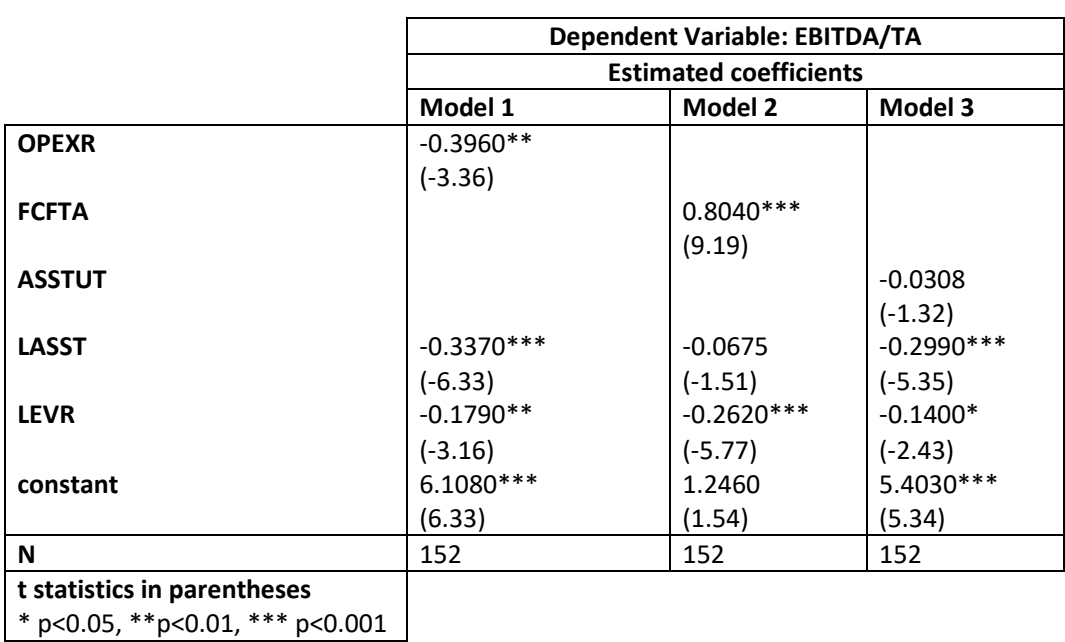

Table 3 provides the fixed year effect panel data regressions based on the three models above. When the results of the first model are analyzed, the influence of agency costs on financial performance is found to be negatively statistically significant. Therefore, the findings of the analysis associated with the first model show that the null hypothesis is rejected; thus, the financial performance mitigating role of agency costs is found to be valid for BIST SME firms for this four-year period. Control variables have also significant effect on EBITDA/TA. The results related to LASST, have significant and negative impact on financial performance which indicate that the small firms can reduce the loss of control and may improve its financial performance. Leverage of the firms has negative impact on financial performance due to significant and negative coefficient. Higher leverage may result increase in financial distress costs or liquidation of firm may cause increase in agency cost of debt (Berger \& Patti , 2006).

The results of second model with respect to FCF/TA provides positive and significant coefficient which is contrary with the expectation of agency cost, measured by the FCF/TA ratio, deteriorates firms' financial performance. According to the free cash flow theory developed by Jensen (1986), the main source of agency costs is free cash flows, and free cash flows reduce the value of the company, especially in companies with low growth opportunities (Demirci, 2017). Accordingly, one of the important factors that cause agency problems is profit, and instead of keeping it within the company when there are no investment opportunities that will increase the value of the company, it should be distributed to shareholders as dividends. Therefore, the distribution of free cash flows to the shareholders will prevent the company from wasting its resources. However, in model 2, this free cash flow theory is not supported. LASST has no statistically significant effect on the firm performance. Other control variable, which is LEVR, again, supports that agency cost may incur when financial distress cost arises.

The last model results show that the ASSTUT ratio, which is an insignificant and negative indirect coefficient, again is contrary to the expectation of agency cost would be higher when firms use their assets inefficient.

\section{CONCLUSION}

This study tries to examine the discussion of agency cost measurement based on the previous literature. The empirical part of the study presents panel data analysis on a dataset of 38 public SME firms traded in Borsa Istanbul between 2017 and 2020 . Three different models are constructed to measure the agency cost in the light of related literature and models utilize three different agency cost proxies.

Operating expense ratio is found as direct measure of agency cost which shows that inefficient spending of managers deteriorates firms' financial performance. The findings of the model 2 with FCF/TA is contrary with the expectation of free cash flow theory. Such results have been found by Wang (2010), which emphasizes two different point; one is higher cash flow may result perquisite consumption of managers and other is cash flow arises from efficiency of managers may result opposite relationship between free cash flow theory and agency cost. Lastly, third model with ASSTUT, has no significant effect on firm performance.

\section{REFERENCES}

Akyol, E. (2007). Temsil Sorunu ve Temettü Politikası Arasındaki İlişkiyi Test Etmeye Yönelik Olarak Türkiye Üzerine Bir Araştırma, Istanbul University, Social Sciences Institute, http://nek.istanbul.edu.tr:4444/ekos/TEZ/43209.pdf.

Anderson, R. C., Mansi, S. A., \& Reeb, D. M. (2003). Founding Family Ownership and the Agency Cost of Debt. Journal of Financial Economics, 263-285.

Ang, J. A., Cole, R. A., \& Lin, J. W. (2000). Agency Costs and Ownership Structure. Journal of Finance, 81-106. 
Berger , A. N., \& Patti , E. B. (2006). Capital Structure and Firm Performance: A New Approach to Testing Agency Theory and an Application to the Banking Industry. Journal of Banking and Finance, 1065-1102.

Berle, A. A., \& Means, G. C. (1932). The Modern Corporation and Private Property. New York: Transaction Publishers.

Chinelo, E. O., \& Iyiegbuniwe, W. (2018). Ownership Structure, Corporate Governance and Agency Cost of Manufacturing Companies in Nigeria. Research Journal of Finance and Accounting, 16-26.

Cole, R. A., \& Mehran, H. (1998). The Effect of Changes in Ownership Structure on Performance: Evidence from the Thrift Industry. Journal of Financial Economics, 291-317.

Çopuroğlu, F., \& Korkmaz, I. H. (2018). Vekalet Teorisi, Sermaye Yapısı ve Firma Performansı Arasındaki Ilişkinin İncelenmesi. G. Ü. İslâhiye iiBF Uluslararası E-Dergi, 21-33.

Demirci, N. S. (2017). Serbest Nakit Akışlarının Şirket Değerine Etkisi: Serbest Nakit Akış Teorisi Bağlamında BIST 100 Endeksi Üzerine Dinamik Panel Veri Analizi. Journal of Business Research, 283-299.

Henry, D. (2006). Agency Costs, Corporate Governance and Ownership Structure: Evidencefrom Australia. Research Gate Publications, 1-44. Jensen, M. C. (1983). Organization Theory and Methodology. The Accounting Review, 319-339.

Jensen, M. C. (1986). Agency Costs of Free Cash Flow, Corporate Finance, and Takeovers. The American Economic Review , 323-329.

Jensen, M. C., \& Meckling, W. H. (1976). Theory of the Firm: Managerial Behavior, Agency Costs and Ownership Structure. Journal of Financial Economics, 305-306.

Margaritis, D., \& Psillaki, M. (2010). Capital Structure, Equity Ownership and Firm Performance. Journal of Banking \& Finance, 621-632.

Morck, R., Andrei, S., \& Vishny, R. W. (1988). Management Ownership and Market Valuation: An Emprical Analysis. Journal of Financial Economics, 293-315.

Rashid, A. (2013). CEO duality and agency cost: evidence from Bangladesh. Journal of Management \& Governance, 989-1008.

Ross, S. A. (1973). he Economic Theory of Agency: The Principal's Problem. The American Economic Review , 134-139.

Singh, M., \& Davidson, W. N. (2003). Agency Cost, Ownership Structure and Corporate Governance Mechanisms. Journal of Banking \& Finance, 793-816.

Smith, A. (1776). The Wealth of Nations. Journal of Financial Economics, 305-360.

Turaboğlu, T. T. (2002). Vekalet Teorisi: Firma Sahiplik Yapısı ve Performans iliş̧kisi Türkiye Uygulaması, Çukurova University, Social Sciences Institute, https://tez.yok.gov.tr/UlusalTezMerkezi/tezDetay.jsp?id=SbTX8MMLtPCDuqOGk1ZCZA\&no=Ri62E1yezBEX0ogSyvCi6w.

Wang, G. Y. (2010). The Impacts of Free Cash Flows and Agency Costs on Firm Performance . Journal of Service Science \& Management, 408418 .

Zhang, H., \& Li, S. (2008). The Impact of Capital Structure on Agency Costs: Evidence from UK Public Companies. South Australia Center Research Papers, 1-18. 